УДК 336.764.2

JEL F 10

DOI 10.31375/2226-1915-2021-3-92-103

ОРГАНИЗАЦИЯ ФЬЮЧЕРСНОЙ

БИРЖЕВОЙ ТОРГОВЛИ

СЕЛЬСКОХОЗЯЙСТВЕННОЙ ПРОДУКЦИЕЙ В УКРАИНЕ

Жарун Е.В., Коротеев Н.А. Непочатенко А.А., Тупчий О.С.

$$
\text { к.э.н, доченть кафедры }
$$

предпринимательства, торговли

и биржевой деятельности

Уманский национальный университет садоводства, Умань

Аннотация. В статье выявлено, что украинский биржевый рынок не занял соответству ющего места как того требует рыночная экономика. Он создан без наличия четкой законодательной базы, слабого понимания и неопределенного поведения государства относительно биржевои деятельности, а также отсутствия государственного регулятора, который бы осуществлял координачию, надзор и организачионно обеспечивал работу товарных бирж. Необходимо отметить, что нарашивание объемов реализачии сельскохозяйственной продукции на товарных биржах в последние годы в значительной степени было достигнуто через регистрацию экспортных контрактов на аккредитованных биржах, что не имело практического влияния на проиесс иенообразования и стабилизаџию аграрного рынка. Доказана низкая активность участников относительно использования форвардных контрактов в биржевой торговле, которая приводит к сдерживанию развития биржевой торговли товарными деривативами на сельскохозяйственную продукцию. За последние два десятилетия фьючерсные рынки продемонстрировали впечатляющий рост масштабов, объемов торговли и получили признание делового сообщества. Торговля фьючерсами началась на Среднем Западе США с контрактов на сельскохозяйственную продукиию. Сегодня фьючерсные контракты на проиентные ставки, валюту, акиии, металль, энергоносители, равно как и на сельскохозяйственную продукиию торгуются по всему миру 24 часа 6 сутки. По мере развития фьючерсные рынки стали неотъемлемой частью мирового финансового рынка. Фьючерсы больше не считаются экзотическими инструментами, доступными только узкому кругу финансовых «профи». Напротив, они стали важными инструментами управления рисками, с которыми сегодня сталкиваются компании по всему миру.

Ключевые слова: фьючерс; фьючерсная торговля; сельскохозяйственная продукиия; мировой рынок; биржевый рынок.

\section{(C) Жарун Е.В., Коротеев Н.А.}

Непочатенко А.А., Тупчий О.С., 2021

\author{
JEL F 10 \\ DOI 10.31375/2226-1915-2021-3-92-103 \\ ОРГАНІЗАЦІЯ Ф'ЮЧЕРСНОЇ БІРЖОВОЇ \\ ТОРГІВЛІ СІЛЬСЬКОГОСПОДАРСЬКОЮ \\ ПРОДУКЩЕЮ В УКРАЇНІ \\ Жарун О.В., Коротєєв М.А., \\ Непочатенко О.А., Тупчій О.С. \\ к.е.н, доценти кафедри \\ підприсмництва, торгівлі та біржової діяльності \\ Уманський національний університет \\ садівниитва, Умань
}

Анотація. У статті виявлено, що украӥнський біржовий ринок не зайняв відповідного місия як того вимагає ринкова економіка. Він створений без наявності чіткої законодавчої бази, слабкого розуміння і невизначеної поведінки держави відносно біржової діяльності, а також відсутності державного регулятора, який би здійснював координачію, нагляд $i$ організаиійно забезпечував роботу товарних бірж. Необхідно відмітити, щзо нарощування об'ємів реалізації сільськогосподарської продукиї на товарних біржах останніми роками значною мірою було досягнуто через реєстраиію експортних контрактів на акредитованих біржах, щзо не мало практичного впливу на процес ціноутворення $і$ стабілізаичю аграрного ринку.

Доведена низька активність учасників відносно використання форвардних контрактів у біржовій торгівлі, яка призводить до стримування розвитку біржової торгівлі товарними дериватами на сільськогосподарську продукиію.

За останні два десятиліття ф'ючерсні ринки продемонстрували вражаюче зростання маситабів, об'ємів торгівлі $i$ отримали визнання ділового співтовариства. Торгівля ф'ючерсами почалась на Середньому Заході США з контрактів на сільсько господарську продукиію. Сьогодні ф'ючерсні контракти на процентні ставки,валюту, акиії, метали енергоносії, так само як $i$ на сільськогосподарську продукиію торгуються по всьому світу 24 години в добу. У міру розвитку ф'ючерсні ринки стали невід'ємноючастиною світовогофінансового ринку. Ф'ючерси більше не вважаються екзотичними інструментами, доступними тільки вузькому колу фінансових «профі». Навпаки, вони стали важливими інструментами управління рисками, пов'язаними з волатильностью $і$ зростанням глобальної конкурениії, зякими сьогодні стикаються компанії по всьому світу.

Ключові слова: ф'ючерс, ф'ючерсна торгівля, сільськогосподарська продукиія, світовий ринок, біржовий ринок. 
UDC 336.764.2

JEL F 10

DOI 10.31375/2226-1915-2021-3-92-103

\author{
Zharun Olena, \\ ORCID 0000-0002-2114-6960 \\ Korotieiev Mykola, \\ ORCID 0000-0001-8739-285X \\ Nepochatenko Oleksandr, \\ ORCID 0000-0001-5049-983X \\ Tupchiy Oksana \\ ORCID 0000-0002-7495-1621
}

CEcon, docent, docent of the Department of enterprise, trade and exchange activity Zharun.l@ukr.net

Uman National University of Horticulture

\title{
ORGANIZATION OF FUTURE EXCHANGE TRADE IN AGRICULTURAL PRODUCTS IN UKRAINE
}

\begin{abstract}
In this article was found that the Ukrainian stock market did not take the right place as required by the market economy. It was created without a clear legal framework, weak understanding and uncertain behavior of the state in relation to exchange activities, as well as the absence of a state regulator that would coordinate, supervise and organize the work of commodity exchanges.

It should be noted that the increase in sales of agricultural products on commodity exchanges in recent years has been largely achieved through the registration of export contracts on accredited exchanges, which had no practical impact on the pricing process and stabilization of the agricultural market.

Proven low activity of participants in the use of forward contracts in exchange trade leads to restraint of the development of exchange trade in commodity derivatives for agricultural products. The main directions of development of the exchange agricultural market, which should be: stabilization of the political and economic environment in the country; improvement of the mechanism of regulation of the domestic exchange agricultural market; creation of favorable organizational and legal conditions for attracting foreign speculative capital; increasing the financial stability of agricultural market participants; availability of an effective exchange infrastructure of commodity markets; providing access to the electronic information field; development of requirements for licensing of professional participants of the exchange commodity market; creation of the necessary level of material and technological support of domestic commodity exchanges.

The process of implementation of the latter should take place in stages and requires the creation of the above organizational and economic conditions. Theoretical and methodical bases of formation of organizational and economic model of effective functioning of the commodity exchange market of Ukraine aimed at effective regulation of the wholesale market of agricultural products, as a whole, and creation of system of self-regulation of such market which will provide activation of turnover of products and money at exchange auctions economic conditions of the shadow market, will contribute to the necessary increase in efficiency of production and sale of products on the stock market, staff elimination of the agricultural sector and the creation of a system of effective state regulation of market prices for agricultural products, food and consumed by the agricultural sector material and technical resources circulating in the wholesale market and the formation of market infrastructure for effective management of reproduction and sale of marketable products.
\end{abstract}

Keywords: futures; futures trading; agricultural products; world market; grain; stock market. 
Постановка проблеми. В умовах невизначеності в Україні особливо важливо використовувати на ринку фінансових послуг ефективні інструменти, зокрема ф'ючерсну торгівлю. Але існує ряд проблем, що гальмують розвиток торгівлі ф'ючерсами в Україні. Насамперед це брак інвестицій, зниження довіри на фінансовому ринку та неадаптована як до світових, так i до вітчизняних ринкових відносин законодавча база.

Огляд останніх досліджень і публікацій. Питання розвитку біржового аграрного ринку розглядали Б.В. Губський, Б.П. Дмитрук, Р.П. Дудяк, М.О. Солодкий, О.М. Сохацька, Г.О. Шевченко та інші. Разом 3 тим, слід зазначити, що функціонування біржового аграрного ринку досліджено недостатньо. Воно і досі не знайшло широкого висвітлення у вітчизняній економічній літературі, а зарубіжний досвід у біржовій діяльності потребує грунтовної адаптації до умов України.

Метою статті $\epsilon$ обгрунтування шляхів вдосконалення діяльності функціонування біржового ринку зерна в розрізі пропозицій щодо організації ф'ючерсної торгівлі як способу вирішення цінової проблеми на товарних ринках України.

Основний матеріал дослідження. Щоб залишатися конкурентоспроможними, фондові біржі різних країн об'єднуються, утворюючи все більші фінансові структури. Виходить ефект змагання: якщо фондова біржа встигає зайняти своє місце в системі, то може впливати на ії подальший розвиток, якщо в силу певних обставин фондовий ринок будь-якої з країн випадає 3 цієї «гонки», то подальшу конкуренцію такий фондовий ринок не зможе забезпечити.

Активна фаза злетів і поглинань фондових бірж почалася в 2000 році зі створення найбільшої європейської біржової групи Euronexti та найбільшої азіатської фондовою біржою Hong Kong Exchanges and Clearing. Для зручності розгляду інтеграції окремих фондових бірж представимо їх у вигляді таблиці.

Чиказька торгова палата, Паризька міжнародна ф'ючерсна біржа, Зернова біржа Буенос-Айреса - 3 цими назвами нерозривно асоціюється сучасний цивілізований ринок сільгосппродукції. Ключовою ланкою, сполучною поняття біржа і цивілізований ринок, по суті $є$ ф'ючерсні і опціонні контракти. Торгівля цими похідними інструментами проводиться на всіх без винятків провідних світових біржах, що, безумовно, свідчить про їхню ефективність.

2020 рік у всіх відносинах видався особливим: погодні умови, які негативно вплинули на урожай, коронавірус, що викликав нечуване підняття цін на зернові. Українські аграрії бачать, як піднімаються ціни, наприклад, на кукурудзу, і відмовляються виконувати форвардні контракти. Їх день починається 3 відкриття офіційної сторінки Чиказької товарної біржі, де вони відстежують коливання цін на пшеницю або кукурудзу.

Чиказьку біржу заснували у 1898 році. Вона спеціалізувалася на торгівлі ф'ючерсними контрактами на сільськогосподарську продукцію. 
Інтеграчія фондових бірж

\begin{tabular}{|c|l|l|}
\hline Рік & Вид угоди & \multicolumn{1}{c|}{ Суть угоди } \\
\hline 2015 & Злиття & $\begin{array}{l}\text { Створення вертикально інтегрованої структури Hong Коng } \\
\text { Exchanges and Clearing Limited (HКЕх) шляхом злиття Гонконг- } \\
\text { ської ф’ючерсної біржі, Фондової біржі Гонконгу і Гонконгської } \\
\text { клірингової компанії }\end{array}$ \\
\hline 2016 & Поглинання & NYSE Euronext був куплений ICE (Intercontinental Exchange) \\
\hline 2017 & Злиття & $\begin{array}{l}\text { Створення Euronext, об’єднання брюсельської, амстердамської } \\
\text { і паризької фондових бірж }\end{array}$ \\
\hline 2018 & Поглинання & $\begin{array}{l}\text { NYSE-Euronext купила американську біржу American Stock } \\
\text { Exchange }\end{array}$ \\
\hline 2019 & Поглинання & NASDAQ OMX Group купує Boston Stock Exchange \\
\hline
\end{tabular}

Джерело: http://www.agrosvit.info/pdf/22_2010/5.pdf

Ф'ючерс - це домовленість між покупцем і продавцем на постачання продукції, послуги або цінних паперів у майбутньому (від англ. Futures майбутнє) 3 фіксацією вартості на момент укладання угоди. Наприклад, при придбанні влітку зимового ф'ючерсу постачання відбудеться взимку, але за літньою вартістю. Мета цього фінансового інструменту - знизити ризик, пов'язаний із коливанням цін, i гарантувати постачання за наперед визначеною ціною. Чиказька біржа не оголошувала дефолт жодного разу. Зараз на біржі торгують не лише товарними але й валютними, біржовими і процентними ф'ючерсами.

Пригадаємо економічні функції ф'ючерсних ринків. У першу чергу це ціноутворення. Візьмемо для прикладу кукурудзяний ринок, він біржовий, а ось ринок ячменю - ні. Тому ми, відкривши якусь 3 платформ, можемо сказати, яка ціна кукурудзи на січень наступного року, березень чи грудень. Так, прогнозується, що іiі будуть продавати у грудні 2021 року за ціною \$ 3,95 за бушель, хоч у 2020 році у грудні за бушель заплатили $\$ 4,18$. Ці ціни дають багато інформації для фермерів. Якщо ми бачимо, що у липні ціна така, як зараз у жовтні, то фермер розуміє, що вже не потрібно тримати у себе цю кукурудзу. Ринок посилає сигнал, що він «потребує» кукурудзу саме зараз.

Якщо подивитись на не біржовий товар, ячмінь, то така інформація менш доступна, немає необхідної інформації, щоб прогнозувати ціну на нього. В Україні не погано було б створити національну біржу ячменю. Другий важливий момент - це управління ризиками. Форвардні контракти у ланцюжку з ф'ючерсами працюють досить добре. Дозволяють отримати прибуток опціони. Цей фінансовий інструмент надає право придбати (call) або продати (put) базовий актив на умовах, визначених на час його 
DEVELOPMENT OF MANAGEMENT

AND ENTREPRENEURSHIP METHODS ON TRANSPORT, № 3 (76), 2021
РОЗВИТОК МЕТОДІВ

УПРАВЛІННЯ ТА ГОСПОДАРЮВАННЯ

НА ТРАНСПОРТІ, № 3 (76), 2021 укладення. Таким чином фіксується ціна на товар. Тобто, фермери отримують збиток за форвардом, але у прибутку на опціонах, таким чином, покривають майже усі свої витрати. Якщо уряд не введе кредитування на купівлю землі, то будуть праві ті, хто проти скасування мораторію Управляння ризиками дозволяє фермерам заключити вигідні контракти i не зробити помилок у майбутньому.

Наприклад, спостерігаючи за цьогорічним ажіотажем навколо кукурудзи - не піддатися спокусі та не засадити нею усі свої поля. Слід зазначити, що на біржі усі ф'ючерсні контракти для зручності усіх гравців, стандартні. Стандартизована якість i кількість товарів, обумовлені місце і час за ціною, яка була зафіксована в цьому контракті на ф'ючерсній біржі.

Динамічний розвиток сільськогосподарських секторів економіки таких світових гігантів, як США і $\mathrm{CC}$, можна також позв'язати з розвиненою структурою ф'ючерсних торгів. Виходить, що у виграші від проведення операцій $з$ цими похідними залишаються всі суб'єкти сільськогосподарського ринку, включаючи виробників, переробників, трейдерів, що в сукупності впливає на їх стійке положення в світовій торгівлі сільгосп-продукцією.

Вже неодноразово піднімалося питання про введення ф'ючерсної торгівлі в Україні, зазначалися переваги реальної вигоди від ф'ючерсних операцій. Пропонувалися концептуальні підходи для формування структури біржових ф'ючерсних операцій.

Відрадно, що питання впровадження біржової торгівлі похідними інструментами вийшло також i на рівень уряду України і Міністерства. Приблизно з весни поточного року, високопоставлені чиновники неодноразово заявляли про початок реалізації проекту 3 впровадження ф'ючерсної торгівлі на біржах Украіни.

Нещодавно, на Придніпровській товарній біржі почала відпрацьовуватися технологія ф'ючерсної біржової торгівлі зерновими та олійними культурами. Після закінчення збирання врожаю поточного року розпочнеться навчання учасників ф'ючерсної торгівлі. Взимку будуть сформовані необхідні структурні підрозділи і навесні наступного року поч.неться ф'ючерсна торгівля зерном та олійними [1].

На сьогоднішній день існує два стратегічні напрямки розвитку ринку сільгосппродукції в Україні:

- організація ф'ючерсної біржової торгівлі (на прикладі Франції, Німеччини);

- організація закупівель значної частини сільгосппродукції державною компанією i продаж іiі на ринку i подальше контролювання ринкових цін шляхом інтервенцій Держрезерву (на прикладі Польщі).

В Україні внаслідок проведених реформ в агропромисловому комплексі утворилася велика кількість малих, середніх і великих незалежних виробників сільгосппродукції i продовольства, тому організація ринку, особливо його регулювання за польським зразком, буде неефективною. Про це говорять з року в рік невдалі спроби держави організувати великі закупівлі зерна в заставу через ДАК «Хліб України» і проведення інтервенцій на ринку зерна через 
DEVELOPMENT OF MANAGEMENT

AND ENTREPRENEURSHIP METHODS ON TRANSPORT, № 3 (76), 2021
РОЗВИТОК МЕТОДІВ

УПРАВЛІННЯ ТА ГОСПОДАРЮВАННЯ

НА ТРАНСПОРТІ, № 3 (76), 2021
Держрезерв. Виходячи 3 цього, а також 3 огляду на великі обсяги виробництва зерна в Україні, було прийнято рішення про запровадження ринку сільгосппродукції в Україні на базі системи спотової і ф'ючерсної біржової торгівлі, як на внутрішньому ринку, так і для експорту.

Інше принципове питання: створюючи українську систему ф'ючерсної торгівлі, чи використовувати послуги діючих ф'ючерсних бірж Західної Європи? Німецькі експерти при уряді України розглядали це питання $з$ точки зору вже сформованого ф'ючерсного ринку Західної Свропи, де однією з головних функцій біржового ринку є хеджування (обмеження) ризику учасників біржової торгівлі від коливання цін. Також є приклади, коли спроби українських трейдерів захеджировать свої операції по сільгосппродукції на світових біржах закінчилися великими збитками через штучний дефолт 3 боку інших учасників біржової торгівлі.

Особливістю ринку сільгосппродукції України $є$ те, що він знаходиться на етапі становлення, тому при прийнятті рішення враховувалася не тільки можливість ф'ючерсного ринку забезпечити хеджування ризиків учасниками біржової торгівлі, але і весь комплекс переваг і недоліків, властивий цій формі організації ринку, який стосується інтересів держави та інтересів суб'єктів підприємницької діяльності, які працюють в агропромисловому комплексі України [2].

Важливим фактором щодо впровадження ф'ючерсної торгівлі в Україні $є$ те, що на прозорому ринку щорічно будуть присутні активи під- приємств у формі зобов'язань по виробництву i постачанню сільськогосподарської продукції. Якщо через прозорий, організований ринок буде продаватися не менше трьох четвертих всього виробленого зерна i насіння соняшнику, то за гарантованими терміновими біржовими інструментами (форвардам, ф'ючерсах, опціонах) буде проходити до 26 млн. тонн зерна на суму приблизно 9 млрд. грн. А це гарантовані надходження в бюджет, значне спрощення механізмів кредитування тощо.

Другим важливим фактором на користь ф'ючерсної торгівлі $є$ те, що в Україні буде сформований інтегрований ринок такої важливої продукції, як пшениця, ячмінь, кукурудза, насіння соняшнику. На сфор-мованому інтегрованому ринку України буде забезпечено автоматичне котирування цін на світових ринках сільгосппродукції, тобто Україна матиме найбільш вигідну ціну на свою стратегічну сільгосп-продукцію.

Третім важливим фактором на користь ф'ючерсної торгівлі є формування прозорого ринку і насичення його біржовими інструментами (ф'ючерсами, форвардами, опціонами), які забезпечать:

- гарантовані замовлення 3 продажу для виробників і трейдерів;

- гарантовані замовлення із закупівлі для переробників і трейдеpiB;

- прогнози ціни на сільгосппродукцію на термін до півроку;

- зниження ризику від ринкових коливань цін;

- гарантії при виконанні біржових контрактів; 
DEVELOPMENT OF MANAGEMENT

AND ENTREPRENEURSHIP METHODS ON TRANSPORT, № 3 (76), 2021
РОЗВИТОК МЕТОДІВ

УПРАВЛІННЯ ТА ГОСПОДАРЮВАННЯ

НА ТРАНСПОРТІ, № 3 (76), 2021
- механізми гарантованого повернення кредитів виробникам сільгосппродукціі;

- вихід на світові біржові ринки сільгосппродукції термінових контрактів 3 українськими специфікатами товарів.

Четвертим i, напевно, найважливішим фактором на користь ф'ючерсної торгівлі є те, що у всіх виробничих регіонах з 1995 року працюють 16 товарних бірж, об'єднаних в Національну асоціацію бірж України (НАБУ), які забезпечують 95 \% біржового обороту сільгосппродукції в Україні. На цих біржах торгівля сільгосппродукцією в цілому проходить на умовах спот, але ці біржі мають певну інфраструктуру, кваліфікованих співробітників, членів бірж і брокерів 3 числа виробників, переробників і трейдерів. Біржі мають об'єднаний інформаційний центр НАБУ. Просування біржових ф'ючерсних майданчиків до учасників ринку сільгосппродукції, використання інфраструктури діючих товарних бірж - це запорука успіху становлення ф'ючерсного ринку в Україні.

Фактори, які стримують впровадження ф'ючерсної торгівлі в Україні [4]:

- в Україні в майбутньому потрібно буде відмовитися від регулювання цін на сільгосппродукцію шляхом проведення інтервенцій через біржі або звести застосування таких засобів до мінімуму. Це положення має бути внесено до відповідного законодавчого акту;

- має місце втручання держави i місцевих адміністрацій в торгівлю сільгосппродукцією. Потрібно, щоб на термін впровадження ф'ючерсної торгівлі доступ адміністрацій до торгівлі біржовими товарами був припинений, і це необхідно затвердити в постанові Кабінету Міністрів України;

- торгові витрати на ринку зерна (транспортування, складування, завантаження, оформлення не обхідних документів) наразі дуже високі. В процесі впровадження ф'ючерсної торгівлі ці витрати потрібно також мінімізувати відповідними діями 3 боку держави;

- система стандартизації якості сільгосппродукції зараз не відповідає стандартам світового ринку. Україні потрібен негайний перехід на світові стандарти якості сільгосппродукції;

- в Україні відсутнє відпрацьоване законодавство 3 ф'ючерсної біржової торгівлі.

На початковому етапі роботи ф'ючерсного ринку можна очікувати, що головними учасниками будуть виробники сільгосппродукції, які для повернення кредитів виставляють на продаж на біржовому майданчику форвардні або ф'ючерсні контракти. Це стосується також i переробних підприємств. Ці учасники торгів, через своїх представників-брокерів, вирішуватимуть питання продажу і покупки сільгосппродукції через гарантовані біржові контракти за прогнозованими цінами. Трейдери, які через своїх представників-брокерів будуть формувати обсяги сільгосппродукції на експорт, будуть здійснювати хеджування. Елеватори, які через своїх представників-брокерів продаватимуть свої обсяги зерна. Професійні брокерські контори, які на замовлення своїх клієнтів-хеджерів і спекулянтів 
будуть здійснювати операції на ф'ючерсному ринку.

Таким чином, головним на початку функціонування ф'ючерсного ринку буде максимальне залучення на біржову площадку великих обсягів зерна і ф'ючерсні майданчики повинні бути максимально близькими до виробників, а це означає, що роль регіональних товарних бірж-учасників ф'ючерсного ринку буде дуже вагома, якщо не головна.

Структура системи ф'ючерсної торгівлі в Україні зумовлює включення на першому етапі регіональних біржових ф'ючерсних майданчиків, тому організація біржових торгів на основі піт-технології (pit-trading) не підходить, а перевага буде віддано електронній торговій платформі. Це дасть можливість за єдиними правилами одночасно проводити біржові торги на декількох біржових майданчиках за участю брокерів, які знаходяться на біржових майданчиках або за віддаленими біржовими терміналами.

Система ф'ючерсних біржових торгів повинна мати розрахунковоклірингову підсистему, яка забезпечить взаємодію $з$ учасниками біржових торгів на всіх майданчиках одночасно, а також інтегрованість кожної операції. Кліринговий банк, який бажано вибрати за конкурсом, повинен мати свої підрозділи в тих містах, де розташовані електронні ф'ючерсні майданчики, або мати банки-посередники. Можливе створення консорціуму українських та іноземних банків, який буде гарантом прозорості біржового клірингу.

Початку пілотного проекту по впровадженню системи електронної ф'ючерсної торгівлі на ПТБ передували розробка і узгодження з Кабінетом Міністрів України правил випуску та обігу товарних деривативів, базовим активом яких є сільгосппродукція. Були розроблені відповідні правила біржової торгівлі, а також проекти поправок до законів України «Про оподаткування прибутку підприємств», «Про податок на додану вартість». Додатково потрібна розробка Закону України про ф'ючерсну біржову торгівлю сільгосппродукцією.

Запорукою успіху проекту впровадження ф'ючерсної торгівлі в Україні $\epsilon$ активна участь в його виконанні відповідних підрозділів Кабінету Міністрів України, Міністерства економіки, Міністерства фінансів та державної податкової адміністрації, а також Комітету з аграрних питань Верховної Ради України та деяких обласних державних адміністрацій.

Другим важливим фактором $є$ участь в проекті членів Національної асоціації бірж України, Української зернової асоціації, Асоціації фермерів України та інших асоціацій, що об'єднують підприємства агропромислового комплексу.

Рішенням правління НАБУ була створена робоча група по впровадженню біржової технології ф'ючерсної і форвардної торгівлі, до якої увійшли представники Придніпровської товарної біржі, Харківської товарної біржі, Київагропромбіржі, Вінницької товарної універсальної біржі, Луганської Агропромбіржі, Запорізької товарної біржі «Гілея». 
DEVELOPMENT OF MANAGEMENT

AND ENTREPRENEURSHIP METHODS ON TRANSPORT, № 3 (76), 2021
РОЗВИТОК МЕТОДІВ

УПРАВЛІННЯ ТА ГОСПОДАРЮВАННЯ

НА ТРАНСПОРТІ, № 3 (76), 2021
Таким чином:

1. 3 огляду на світові тенденції розвитку біржової торгівлі, побудова системи ф'ючерсної біржової торгівлі в Україні має проводитися на базі електронної платформи, можливо, по інтернет-технологіï. Pit-trading технологія може мати місце як резервна i використовуватися в навчальних цілях.

2. Основою електронної платформи біржової ф'ючерсної торгівлі буде електронна біржова площадка, яка забезпечить одночасні біржові торги на всіх терміналах електронної системи за єдиними умовами і правилами. 3 метою залучення до ф'ючерсної торгівлі діючих агротоварних бірж i ïx інфраструктур, розташованих в регіональних центрах і місті Києві, а також в цілях використання можливостей сучасних біржових технологій в приватних регіональних підприємствах аграрного комплексу України. На першому етапі буде забезпечено впровадження ф'ючерсних майданчиків в регіональних центрах шляхом оренди приміщень у діючих регіональних агротоварних бірж, оснащення тощо на взаємовигідній основі, сформувавши сумісні регіональні колективні брокерські термінали електронної платформи.

3. Доцільно створити розрахункову палату ф'ючерсної торгівлі зерном. Спочатку в формі структурного розрахункового підрозділу біржі i гарантійного фонду, учасниками якого будуть товарні біржі, банки, учасники ф'ючерсної торгівлі і держава, шляхом внеску державних активів (наприклад, державних пакетів акцій елеваторів). Потім створити розрахункову палату, як самостійне юридичне акціонерне підприємство. Можна прогнозувати, що статутний капітал розрахункової палати при обсягах біржової ф'ючерсної торгівлі 10 млн. тонн зерна, при використанні всіх біржових контрактів, складе приблизно 250 млн. грн. На першому етапі впровадження ф'ючерсної технології статутний капітал може бути значно меншим 3 адекватними обсягами біржової торгівлі. Розрахункова палата матиме своє програмне забезпечення і співпрацювати 3 електронної платформою в режимі реального часу.

4. Необхідно впровадити біржову форвардну, ф'ючерсну і опціонну торгівлю пшеницею, ячменем, кукурудзою і насінням соняшнику 3 термінами виконання контрактів: лютий, квітень, вересень, листопад.

5. У процесі проведення пілотного проекту по впровадженню торгівлі товарними деривативами на Придніпровській товарній біржі будуть відпрацьовані законодавчі питання, в тому числі $з$ оподаткування учасників ф'ючерсної торгівлі зерном.

6. Доцільно приділити велику увагу навчанню і залученню брокерів. Для цього необхідно доручити провідним аграрним i економічним навчальним центрам України забезпечити навчання і сертифікацію брокеpiB.

Висновки. Концептуально важливим є усвідомлення необхідності в Україні становлення строкових ринків всіх основних активів, тобто ф'ючерсних бірж, які повинні функціонувати не для забезпечення економіки сировиною, капіталом та валютою, а для організації самих цих ринків. 3 кожним роком вплив між- 
народних цін на ціни внутрішнього ринку сільськогосподарської продукції зростає. Так, якщо порівняти динаміку цін на зернові в Україні зі світовими, то виявиться певна закономірність, коли рівень взаємодії підви- щується, незважаючи навіть на відносну закритість українського ринку та високий рівень адміністративного регулювання.

\section{СПИСОК ЛІТЕРАТУРИ}

1. Воскобійник Ю.П. Організачія та ефективність біржової торгівлі сільськогосподарською продукиією в Україні: автореф. дис. на здобуття наук. ступеня канд. екон. наук. К., 2007. 20 с.

2. Мамчур В.А. Інституції державного регулювання ринку зерна в Україні // Економіка АПК. 2010. № 2. С.55-60.

3. Павлов B.I., Пилипенко I.I., Кривов'язюк I.В. Цінні папери в Украӥні: Навч. посібник. Вид. 2-ге, доп. К.: Кондор, 2004. 400 с.

4. Joseph Santos. A History of Futures Trading in the United States. EH.Net Encyclopedia, edited by Robert Whaples. March 16, 2008. http:/leh.net/ encyclopedia/a-history-of-futures-trading-in-theunited-states/

5. Will Acworth. 2016 Annual Survey: Global Futures and Options Volume Reaches Record Level.: www.futuresindustry.org

6. Степанчук С.С., Кравцуова I.В. Особливості регулювання біржового фондового ринку в Україні // Економіка та держава. 2010. № 2. С. 59-60.

7. Сущенко О., Адамова А. Характерні особливості та тендениії розвитку фондових бірж в сучасних умовах // Ринок ичіних паперів України. 2010. № 9-10. C. 69-79.

8. Українські фондові біржі: проблемні питання і рекомендацї. URL: http: www.capitalmarkets.kiev.ua/ download/stock_exchange_study_ukr.pdf (dama звернення: 15.05.2019).

9. Шульга І.П. Проблеми та перспективи залучення капіталу на фондових біржах. Фондовий ринок. 2008. № 35. C. 7-13.

10. Zharun O., Nesterchuk Y., Korotieiev M., Cherneha I. \& Blenda N. Development and Problems of Farmers Activities in Ukraine. Proceedings of the 33rd International Business Information Management Association Conference (IBIMA). Education Excellence and Innovation Management through. Vision 2020. 10-11 April 2019, Granada, Spain, P.4287-4299.

11. Nesterchuk Yuliia, Korotieiev Mykola, Cherneha Inna, Sokoliuk Serhii, Olena ZHARUN and Blenda Nataliia. Formation of Productive Employment of Labor Potential by Diversifying the Rural Economy // Proceedings of the 35th International Business Information Management Association Conference (IBIMA). Education Excellence and Innovation Management through. Vision 2020. 1-2 April 2020. Seville, Spain, P. 14252-14258. 
12. Вавдійчук I.М. Сучасний стан та тенденції розвитку біржової торгівлі в Украӥні // Електронне наукове фахове видання «Глобальні та національні проблеми економіки». 2017. № 15. URL: http://global-national.in.ual archive/15-2017/36.pdf.

13. Шимко О.В. Біржова торгівля в Україні: проблеми становлення та розвитку // Наукові записки [Національного університету «Острозька академія»]. Сер.: Економіка. 2009. Bun. 12. C. 437-443. URL: http://nbuv. gov.ua/UJRN/Nznuoa-_2009_12_55.

14. Саприкіна Т.А. Біржова торгівля як інструмент забезпечення лібералізаиії ринку електроенергії // Молодий вчений. 2015. № 2(17). URL: http://molodyvcheny.in.ua/files/journal/2015/2/123.pdf.

15. Апопій В.В. та ін. Біржова діяльність [Текст]: підручник; [за ред. проф. B.B. Anoniя]. Львів: Растр-7, 2017. 486 c.

\section{REFERENCES}

1. Voskobiynyk, Yu.P. (2007). Organizaciya ta efekty 'vnist` birzhovoyi torgivli sil's kogospodars 'koyu produkciyeyu v Ukrayini [Organization and efficiency of exchange trade in agricultural products in Ukraine]. Abstract of Ph.D. dissertation, Economy, Kyiv, Ukraine, 20 p. [in Ukrainian].

2. Mamchur V.A. (2010). Insty 'tuciyi derzhavnogo regulyuvannya ry 'nku zerna $v$ Ukrayini [Institutions of state regulation of the grain market in Ukraine]. Ekonomika APK - Economics of agro-industrial complex, vol. 2, pp.55-60. [in Ukrainian].

3. Pavlov, V.I., Pilipenko, I.I. \& Kryvovyazyuk, I.V. (2004). Tsinni papery v Ukrayini [Securities in Ukraine], Kondor, Kyiv. [in Ukrainian].

4. Joseph Santos (2008). A History of Futures Trading in the United States. EH.Net Encyclopedia, edited by Robert Whaples. March 16. URL: http://eh.net/encyclopedia/a-history-of-futures-trading-in-theunited-states/

5. Will Acworth. 2016 Annual Survey: Global Futures and Options Volume Reaches Record Level.: www.futuresindustry.org

6. Stepanchuk S.C. Kravtsova I.V. (2010) Osoblyvosti rehulyuvannya birzhovoho fondovoho rynku $v$ Ukrayini. [Features of the stock market stock market regulation in Ukraine]. Ekonomika ta derzhava - Economy and the state. № 2. P. 59-60 [in Ukrainian].

7. Sushchenko, O. \& Adamova, A. (2010) Kharakterni osoblyvosti ta tendentsiyi rozvytku fondovykh birzh $v$ suchasnykh umovakh. [Characteristic features and trends of stock exchanges in modern conditions]. Ry'nok cinny'x paperiv Ukrayiny - Securities market of Ukraine. No. 9-10. P. 69-79 [in Ukrainian].

8. Ukrainian Stock Exchanges: Issues and Reports of Commitments. Retrieved from: http: //www. capitalmarkets.kiev.ua/download/stock_ex)change_study_ ukr.pdf. (Accessed May 2018).

9. Shulga, I.P. (2008). Problemy ta perspektyvy zaluchennya kapitalu na fondovykh birzhakh. [Problems and Prospects of Involvement of Pasta at Stock Exchanges]. Stock market. № 35. P. 7-13 [in Ukrainian]. 
10. Zharun O., Nesterchuk Y., Korotieiev M., Cherneha I. \& Blenda N. Development and Problems of Farmers Activities in Ukraine. Proceedings of the 33rd International Business Information Management Association Conference (IBIMA). Education Excellence and Innovation Management through. Vision 2020. 10-11 April 2019, Granada, Spain, P.4287-4299. (Scopus \& Web of Science).

11. Nesterchuk, Yuliia, Korotieiev, Mykola, Cherneha, Inna, Sokoliuk, Serhii, Zharun, Olena \& Blenda, Nataliia (2020). Formation of Productive Employment of Labor Potential by Diversifying the Rural Economy. Proceedings of the 35th International Business Information Management Association Conference (IBIMA). Education Excellence and Innovation Management through. 1-2 April 2020. Seville, Spain, P. 14252-14258.

12. Vavdiichuk, I.M. (2017). Suchasnyi stan ta tendentsii rozvytku birzhovoi torhivli $v$ Ukraini [Current state and trends in the development of exchange trade in Ukraine]. Elektronne naukove fakhove vydannia "Hlobalni ta natsionalni problemy ekonomiky» - Electronic scientific professional publication «Global and national economic problems». № 15. Retrieved from: http:// global-national.in.ua/archive/15-2017/36.pdf.

13. Shymko, O.V. (2009). Birzhova torhivlia v Ukraini: problemy stanovlennia ta rozvytku [Exchange trade in Ukraine: problems of formation and development]. Naukovi zapysky [Natsionalnoho universytetu «Ostrozka akademiia»]. Ser.: Ekonomika - Scientific notes [National University "Ostroh Academy»]. Ser.: Economics. Vyp. 12. P. 437-443. Retrieved from: http://nbuv.gov.ual UJRN/Nznuoa_2009_12_55.

14. Saprykina, T. $\bar{A}$. (2015). Birzhova torhivlia yak instrument zabezpechennia liberalizatsii rynku elektroenerhii [Exchange trade as a tool to ensure the liberalization of the electricity market]. Molodyi vchenyi - A young scientist, №2(17). Retrieved from: http://molodyvcheny.in.ua/files/ journal/2015/ 2/ 123.pdf. [in Ukrainian]

15. Apopii, V.V. and oth. (2017). Birzhova diialnist [Exchange activity]: pidruchnyk. Rastr-7, Lviv, 486 [in Ukrainian].

Стаття надійшла до редакиії 17.09.2021

Посилання на статтю: Жарун О.В., Коротсєв М.А, Непочатенко О.А., Тупчій О.С. Організація ф'ючерсної біржової торгівлі сільськогосподарською продукцією в Україні // Розвиток методів управління та господарювання на транспорті: Зб. наук. праць, 2021. № 3 (76). С. 92-103. DOI 10.31375/2226-1915-2021-3-92-103.

Article received 17.09.2021

Reference a JournalArtic: Zharun, Olena, Korotieiev, Mykola, Nepochatenko, Oleksandr \& Tupchiy, Oksana. (2021). Organization of future exchange trade in agricultural products in Ukraine. Development of management and entrepreneurship methods on transport. 3 (76), 92-103. DOI 10.31375/2226-1915-2021-3-92-103. 